\title{
ETIČKO KORIŠTENJE INTERNETA I LAŽNI PROFILI
}

\author{
Smiljana PERIĆ, prof. savjetnik \\ II. gimnazija, Križanićeva 4, 10000 Zagreb \\ smiljana.peric@skole.hr \\ Gordana SEKULIĆ-ŠTIVČEVIĆ, prof. savjetnik \\ I. gimnazija, Avenija Dubrovnik 36, 10000 Zagreb \\ gordana.sekulic-stivcevic@skole.hr \\ Dunja MARUŠIĆ BREZETIĆ, ravnateljica \\ I. gimnazija, Avenija Dubrovnik 36, 10000 Zagreb \\ dunja.marusic@skole.hr
}

\section{SAŽETAK}

Sredinom 2020. provedeno je anketiranje 477 ispitanika (354 učenika i 123 nastavnika). Anketa je propitivala stavove učenika i nastavnika iz više škola o različitim situacijama vezanima uz korištenje interneta i ostavljanje digitalnih tragova. Među anketnim pitanjima nalazilo se i devetnaest pitanja vezanih uz etičko korištenje interneta. Početna hipoteza bila je da nastavnici imaju bolje definirane stavove o etičkim pitanjima nego učenici. Pretpostavili smo da s obzirom na aktualnost teme i profesiju kojom se bave nastavnici više promišljaju o opasnostima na internetu te da imaju čvršće formirane moralne stavove. Anketa je u većoj mjeri potkrijepila tu hipotezu.

Ključne riječi: škola, internet, etika, lažni profili.

\section{UVOD}

Krenuli smo od hipoteze da nastavnici imaju bolje definirane stavove o etičkim pitanjima nego učenici. Objašnjenje hipoteze: polje etičkog promišljanja proširilo se i na međuljudsko djelovanje u virtualnom svijetu. Svjedoci smo da učenicima (digitalnim urođenicima) često upravo virtualni prostor postaje mjesto veće aktivnosti nego fizički svijet. Boravak na internetu, informiranje o svijetu preko interneta, a posebno interakcija s poznatim ili nepoznatim osoba preko različitih društvenih mreža predstavlja važan 
S. Perić, G. Sekulić-Štivčević, D.Marušić Brezetić, Etičko korištenje interneta i lažni profili

segment života mladih, često povezan s opadanjem kontakata i druženja uživo. Etika kao filozofska disciplina koja proučava moral (skup pravila koja definiraju što je dobro, a što zlo) počiva na odgovoru na pitanje zašto je nešto ispravno (dobro), a nešto neispravno (zlo). Iako je virtualni svijet kreirao neke nove vrste komunikacije i interakcije koje su dovele do stvaranja tzv. internet bontona, $\mathrm{i}$ dalje ima prostora da se ponašanja $u$ virtualnom svijetu sagledaju s pozicije tradicionalne etike s obzirom da se i dalje radi o međuljudskim odnosima, jedino što su oni sada posredovani drugim medijem. $U$ tom segmentu je primjenjiva analogija moralnih pravila iz svijeta ,licem u lice“ na svijet „ekranom na ekran“. Naravno, postoje i segmenti gdje ta analogija nije primjenjiva jer su se pojavile posve nove situacije $\mathrm{i}$ odnosi (npr. influencerstvo, maksimalna mogućnost anonimnosti/lažnih identiteta...).

Istraživanje kreće od pretpostavke da godine koje sa sobom nose veće obrazovanje i iskustvo igraju važnu ulogu pri definiranju stavova o ponašanju na internetu koje ulazi $u$ sferu etičkog. Pretpostavili smo da nastavnici više razmišljaju o tome što je etično, a što nije, sagledavaju stvari iz više perspektiva i mogu bolje obrazložiti svoja stajališta.
Istraživanje je bilo anonimno i provedeno je putem Google Formsa.

Sudjelovalo je 123 nastavnika i 354 učenika, odnosno bilo je ukupno 477 anketiranih osoba.

Anketirano je 146 učenika I. gimnazije i 150 učenika II. gimnazije iz Zagreba te 58 učenika Ekonomske i trgovačke škole Čakovec.

Među učenicima anketa je provedena je tijekom veljače i ožujka 2020,, a nastavnici su anketirani od 24. lipnja do 4. srpnja 2020. godine.

Ankete za učenike i profesore nalaze se na sljedećim poveznicama:

- Za nastavnike: https://forms.gle/taWK7Aq8dbFsDZ $\underline{\mathrm{dD} 7}$

- $\mathrm{Za}$ učenike Prve gimnazije: https://forms.gle/cmEqpakDqhoBUY qE8

- Za učenike Druge gimnazije: https://forms.gle/NPkPoRkSAhWvL $\underline{\mathrm{bXu} 5}$

- Za učenike ETS̆ Čakovec: https://forms.gle/ZswMjmMVZWko $\underline{\operatorname{dnj} y 7}$ 


\section{PREGLED REZULTATA}

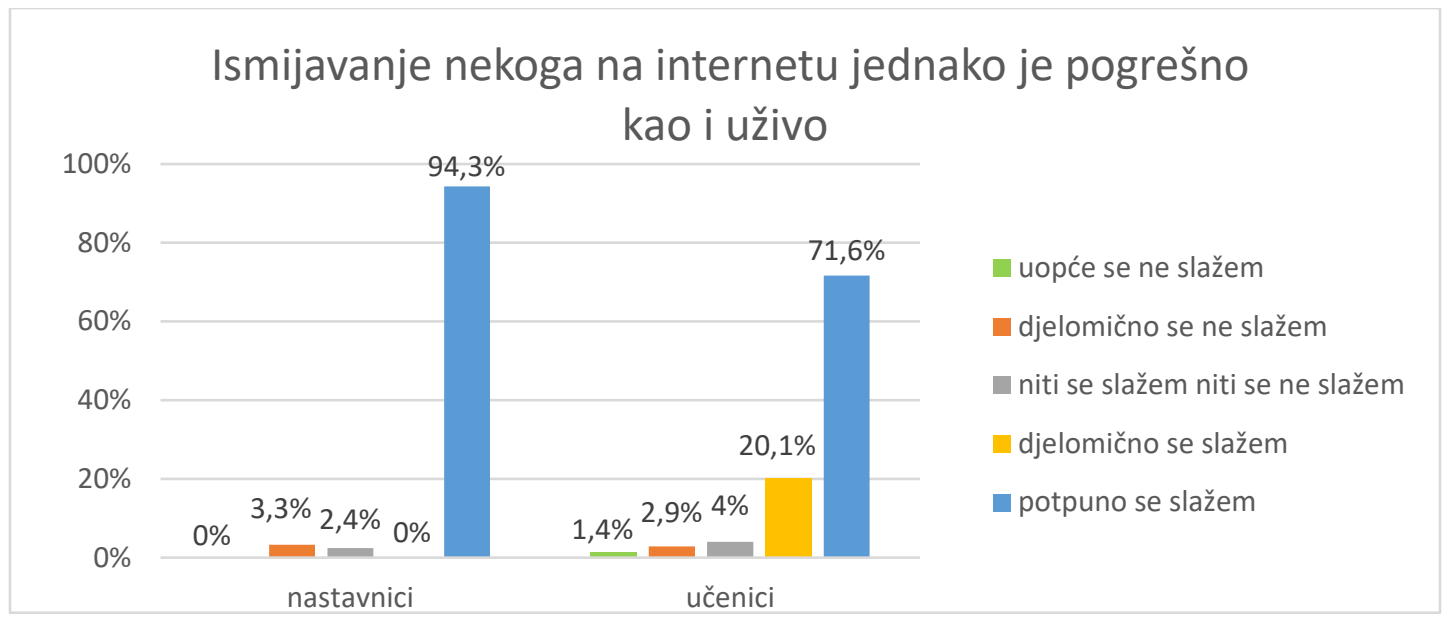

Grafikon 1. Ismijavanje na internetu

Nastavnici su u velikom broju svjesni da je svako ismijavanje druge osobe pogrešno neovisno o tome odvija li se uživo ili na internetu. Među učenicima postoji mali postotak onih koji se uopće ne slažu s tvrdnjom da je ismijavanje nekoga na internetu jednako pogrešno kao i uživo dok među nastavnicima nema takvih odgovora

\subsection{Smeta mi kad netko objavljuje moje fotografije bez mog znanja i dopuštenja}

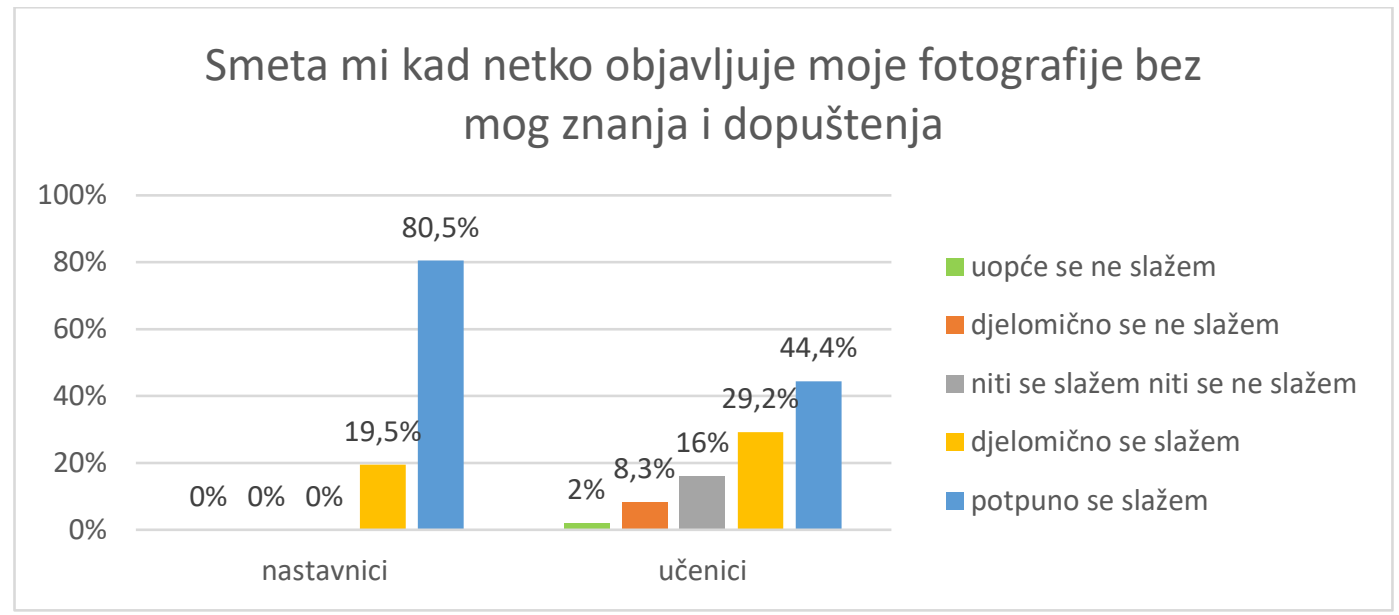

Grafikon 2. Objavljivanje fotografija bez našeg znanja i dopuštenja

Iz odgovora je vidljivo da nastavnicima znatno više smeta kad netko objavljuje njihove fotografije bez znanja i dopuštenja. Učenicima to ne smeta u tolikoj mjeri 
S. Perić, G. Sekulić-Štivčević, D.Marušić Brezetić, Etičko korištenje interneta i lažni profili

1.2. I sam sam ponekad objavljivao fotografije na kojima se nalaze drugi ljudi, a da ih nisam pitao/la za dopuštenje

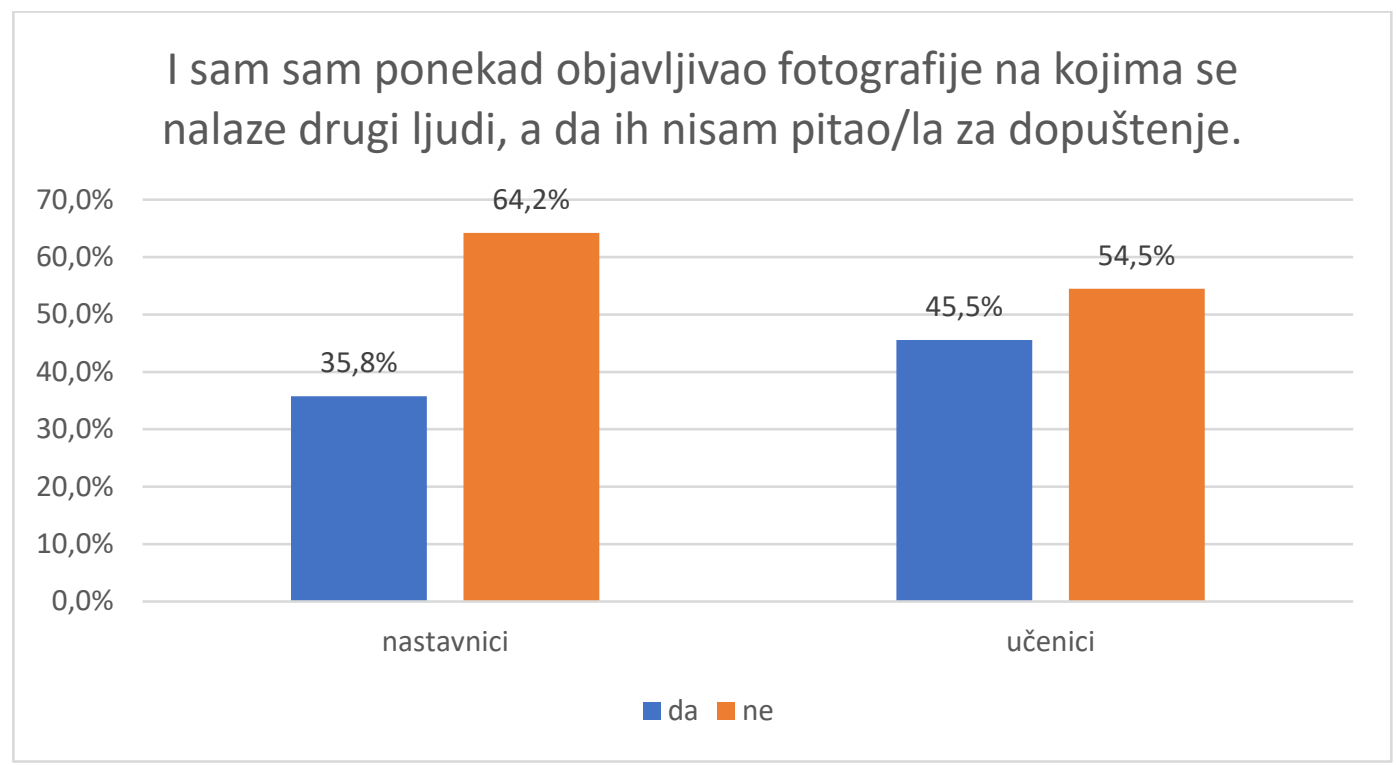

Grafikon 3. Objavljivanje tuđih fotografija bez dopuštenja

Iako se preko $80 \%$ nastavnika izjasnilo da im smeta da netko objavljuje njihove fotografije bez znanja i dopuštenja, njih 35\% je bilo svjesno da su to i sami radili. Među skoro $65 \%$ ostalih nastavnika postoji značajan broj onih koji nisu vodili računa o tome da se negdje u „drugom planu“ fotografije često nalaze još neke jasno prepoznatljive osobe (zajednička druženja na stručnim skupovima, obiteljskim okupljanjima i drugim prigodama).

Istovremeno, malo manje od polovice učenika se izjasnilo da su objavljivali tuđe fotografije bez dopuštenja, što je bilo očekivano, jer je na prethodno pitanje približno isti broj učenika odgovorio da im uopće ne smeta ako drugi to rade. 


\subsection{Ako vidim da je netko ostao prijavljen na e-mailu ili društvenoj mreži nije ništa loše ako pogledam dostupne sadržaje}

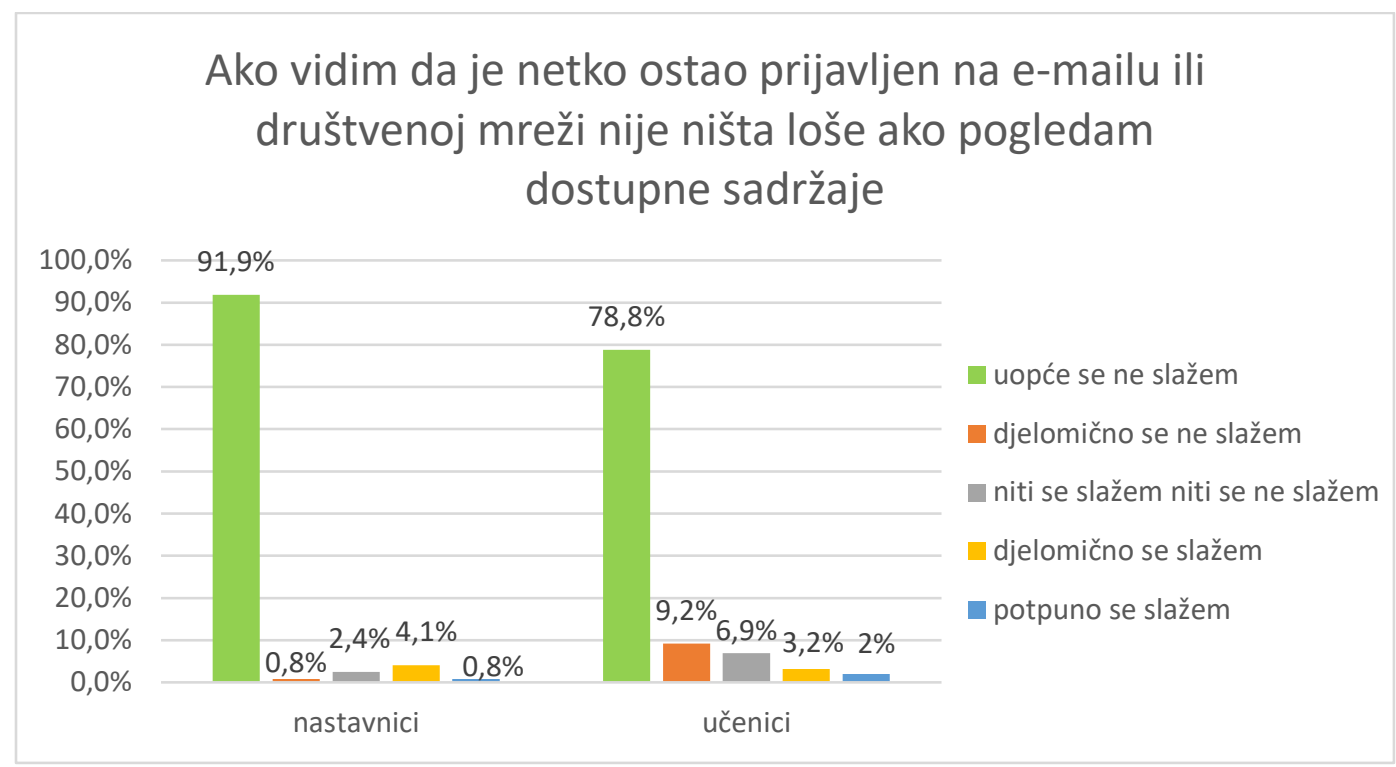

Grafikon 4. Pregledavanje tuđih sadržaja

Velika većina ispitanika svjesna je da je ulazak u tuđi e-mail ili društvenu mrežu moralno neispravan, ali dio ipak smatra da to nije pogrešno te da je to problem onoga tko je ostao prijavljen. Nešto veći udio učenika nego nastavnika razmišlja na taj način.

\subsection{Ako bih došao u posjed tuđe lozinke, vjerojatno bih se ,ulogirao“s s tuđim podacima}

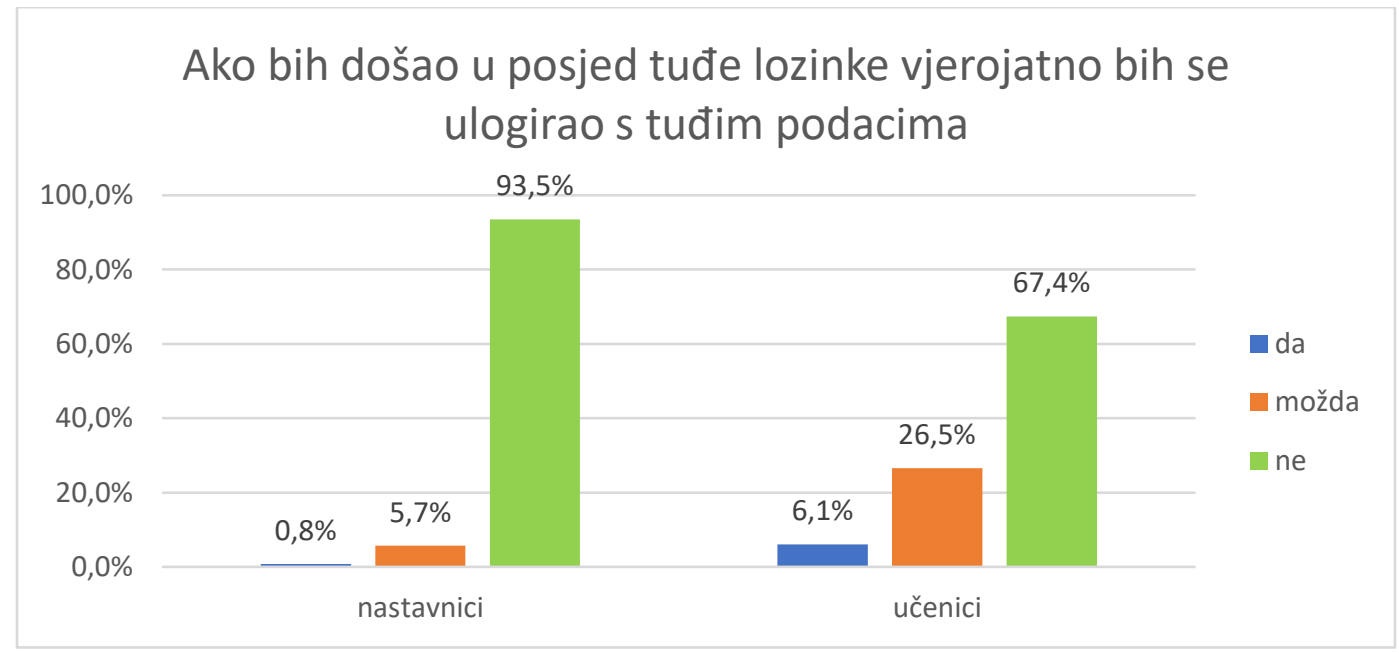

Grafikon 5. Korištenje tuđe lozinke 
S. Perić, G. Sekulić-Štivčević, D.Marušić Brezetić, Etičko korištenje interneta i lažni profili

Manje od $1 \%$ nastavnika iskoristilo bi posjedovanje tuđih podataka kako bi se ulogiralo na tuđi račun, a oko $6 \%$ njih bi se možda ulogirali. Kod učenika je taj broj znatno veći. Preko 30\% učenika bi se sigurno ili možda ulogirali. U odnosu na prethodno pitanje gdje se samo pregledava sadržaj jer se netko nije odjavio u ovom slučaju znatiželja se može utažiti samo ako se iskoriste tuđi pristupni podaci. Kod profesora bi taj korak učinilo još manje njih nego u prethodnom pitanju, ali kod učenika je postotak veći.

\section{5.,Lajkam“ i ono što mi se ne sviđa ako mislim da bi se naljutili autori objave}

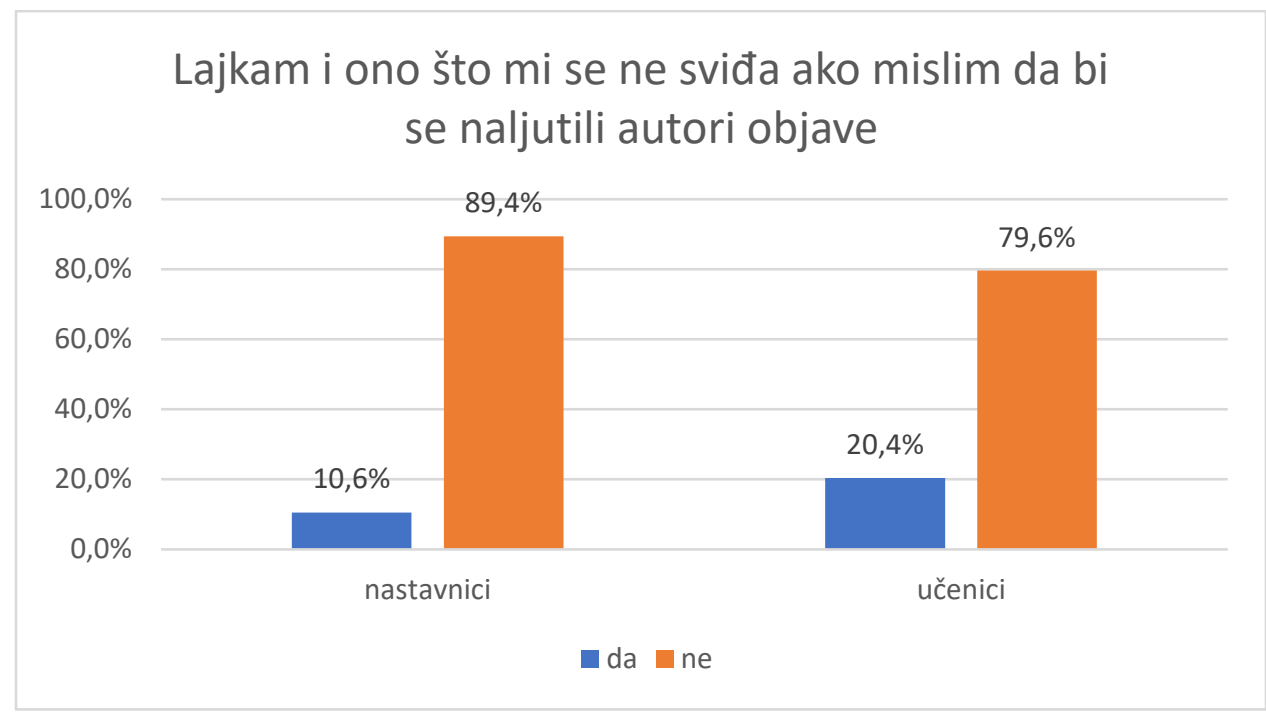

Grafikon 6. Lajkanje sadržaja

Više od 10\% nastavnika i 20\% učenika lajkaju i dijele objave kako se ne bi naljutili autori objave. U odgovoru na pitanje vidi se kako se ispitanici nose $\mathrm{s}$ društvenim pritiskom pa je očekivano da mu učenici više podliježu iz želje za uklapanjem i prihvaćanjem 


\subsection{Uspoređujem broj „lajkova“ mojih i tuđih objava}

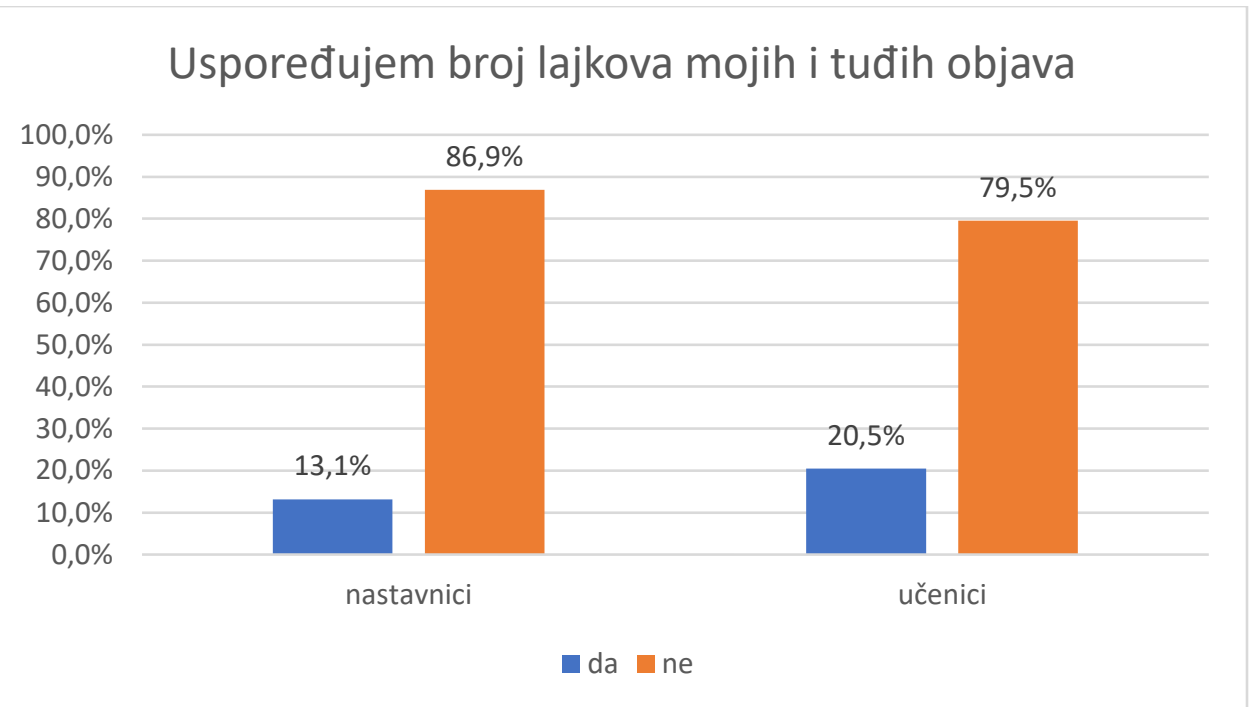

Grafikon 7. Uspoređivanje broja lajkova

Očekivali smo da će veći postotak učenika (prema anketi 20\%) uspoređivati svoje lajkove i lajkove svojih kolega, ali i da će manji broj nastavnika to činiti (prema anketi oko 13\%). Dakle, rezultat je očekivan. Procjena vlastite popularnosti i prihvaćenosti u odnosu na vršnjake tipičnija je za adolescentsku nego za odraslu dob

\subsection{Mnogi ljudi objavljuju preintimne sadržaje na društvenim mrežama}

Mnogi ljudi objavljuju preintimne sadržaje na društvenim mrežama

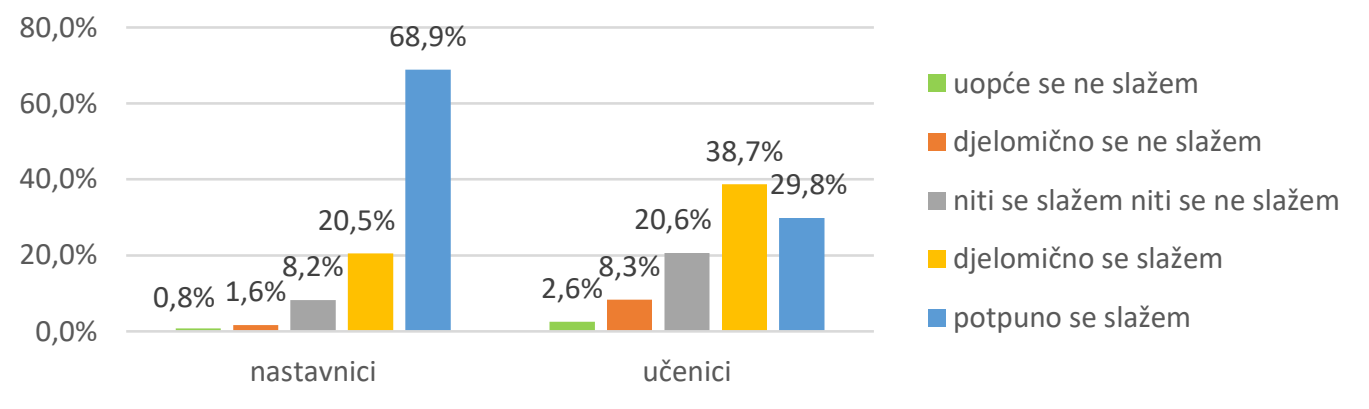

Grafikon 8. Sadržaji na društvenim mrežama 
S. Perić, G. Sekulić-Štivčević, D.Marušić Brezetić, Etičko korištenje interneta i lažni profili

Velik postotak nastavnika potpuno se slaže s tvrdnjom. Ipak. često možemo vidjeti nastavnike koji objavljuju slike iz svog doma, s obiteljskih okupljanja i druženja. Ovo je jedno od pitanja u kojem se odgovori profesora i učenika u velikoj mjeri razlikuju. Učenici imaju manje stroge kriterije $u$ procjeni što je intimno, a što ne i dosta viši prag tolerancije za sadržaj objavljen na internetu.

\subsection{Onaj tko objavi neprimjereni sadržaj odgovorniji je nego onaj tko je taj isti sadržaj samo podijelio dalje (objava nekog neprimjerenog sadržaja i njegovo dijeljenje nemaju istu ,težinu“)}

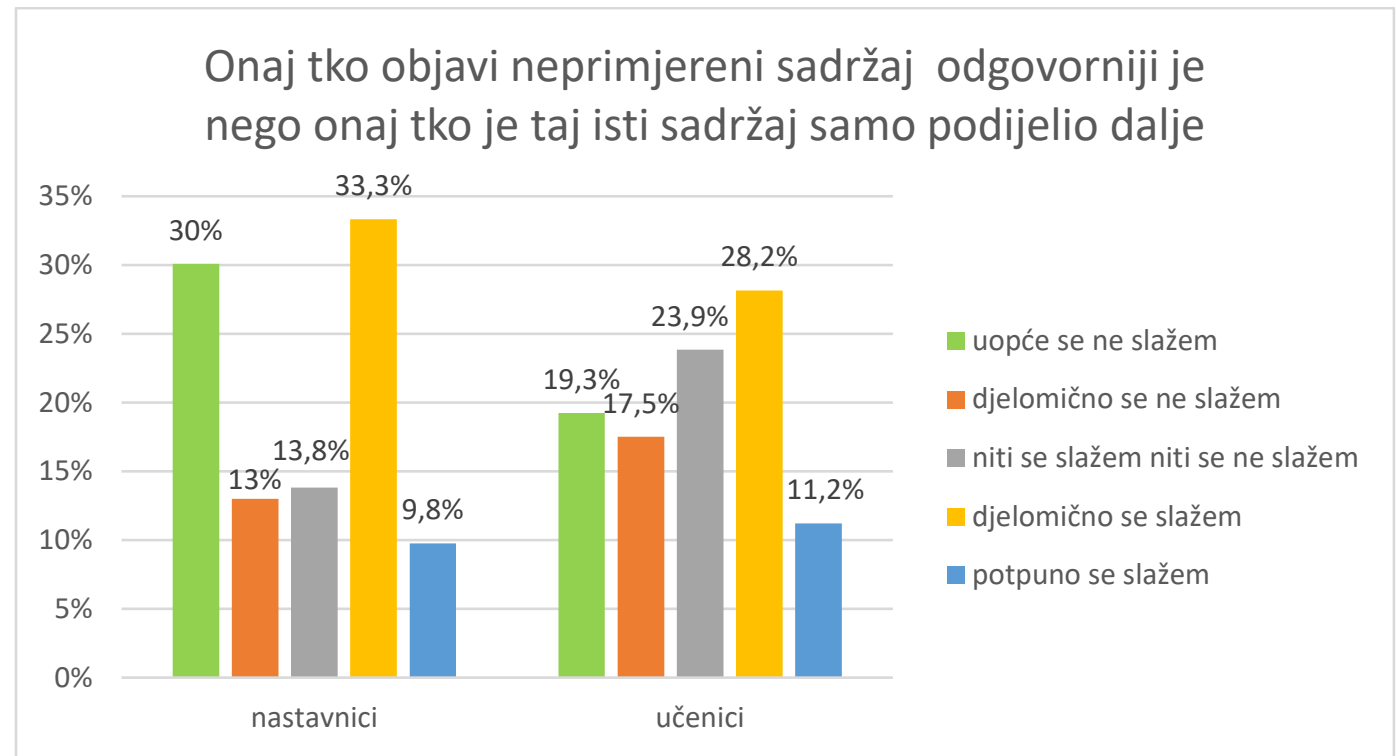

Grafikon 9. Odgovornost za objavljivanje sadržaja na mrežama

I profesori i učenici su u najvećoj mjeri djelomično slažu da je odgovorniji onaj tko objavi nešto neprimjereno nego onaj tko to prosljeđuje. Stav da je odgovornost podjednaka (odgovor: uopće se ne slažem) odabralo je značajnije više profesora nego učenika. 


\subsection{Ostavio sam negativan komentar, iako sam znao/la da može povrijediti drugu osobu}

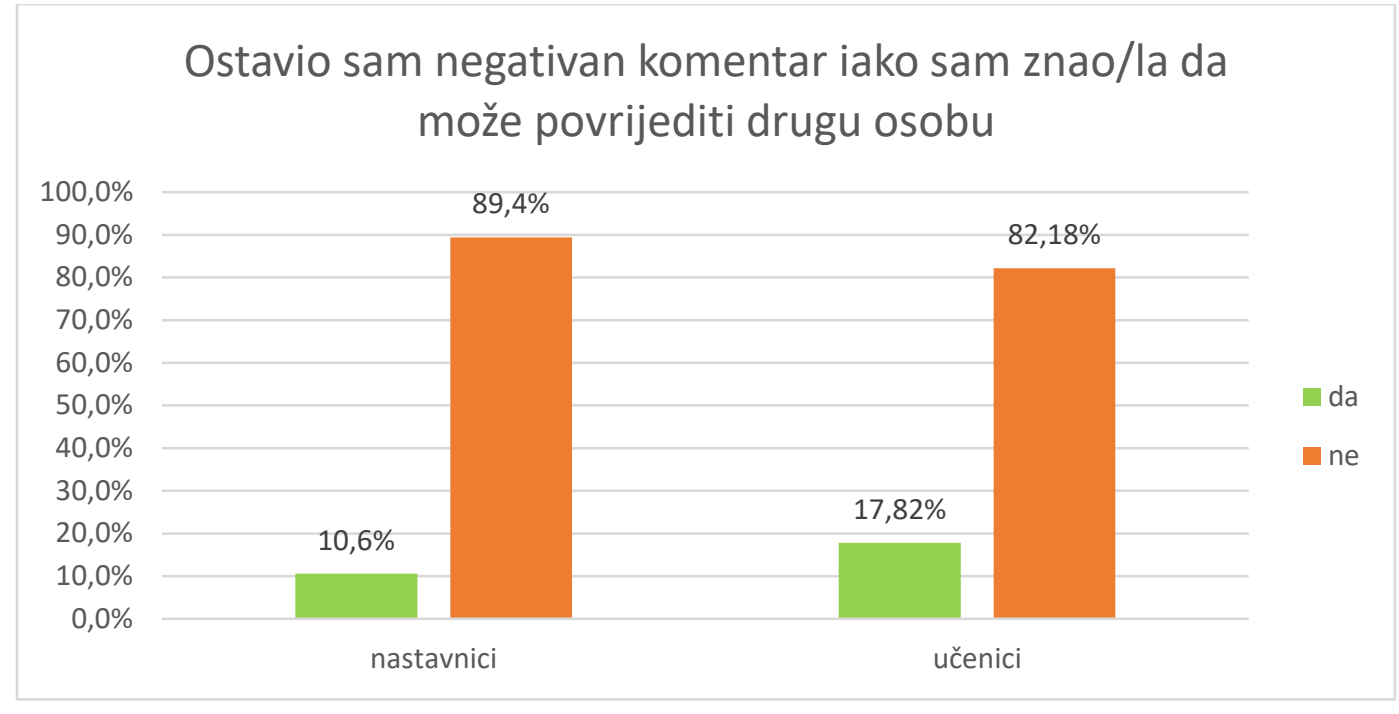

Grafikon 10. Ostavljanje negativnih komentara

I profesori i učenici ostavljali su negativne komentare u manjoj mjeri.

\subsection{Trebalo bi zabraniti objavljivanje snimki koje prikazuju događaje u kojima je netko poginuo ili ozbiljno stradao}

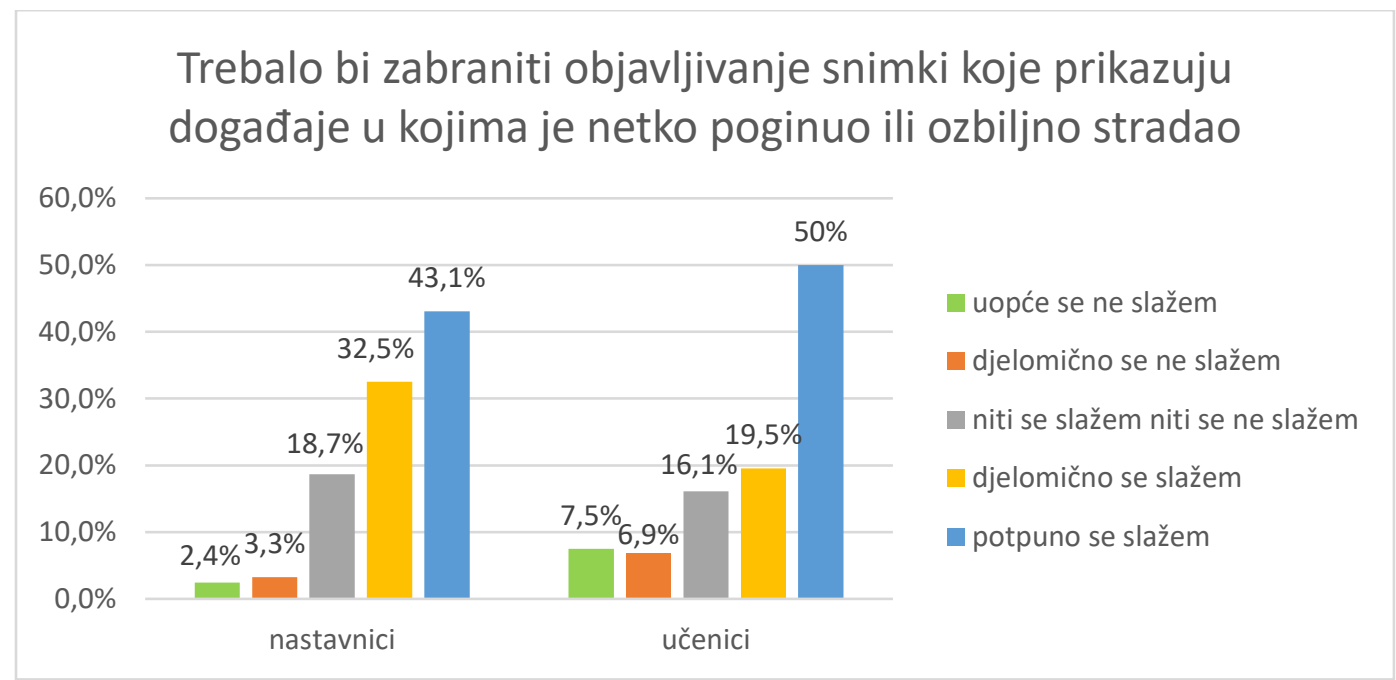

Grafikon 11. Zabranjivanje objavljivanja snimki ozbiljnih stradavanja

Iako nije precizirano zbog čega se takve snimke potencijalno objavljuju (informacija ili zabava) najviše ispitanika se potpuno slaže da bi se te snimke trebalo zabraniti. Nešto je veći postotak učenika koji tako misle nego profesora. 
S. Perić, G. Sekulić-Štivčević, D.Marušić Brezetić, Etičko korištenje interneta i lažni profili

\subsection{U zatvorenim grupama nije pogrešno nekoga vrijeđati i ismijavati (ako ta osoba nije član grupe)}

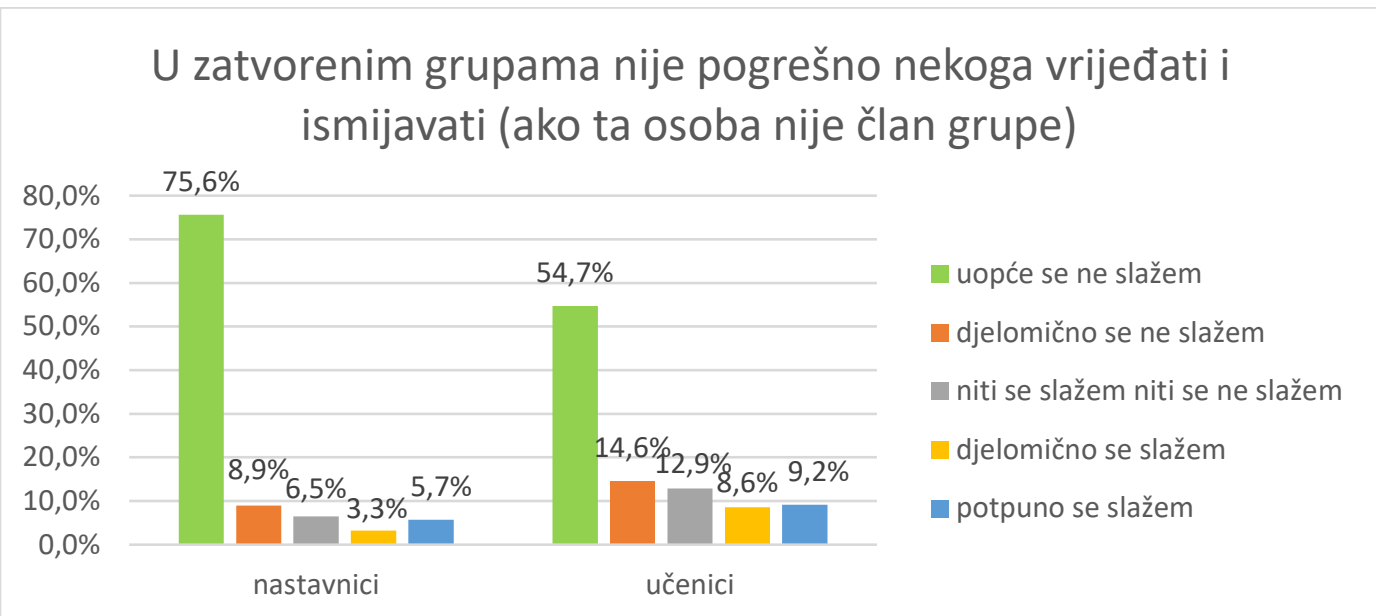

Grafikon 12. Vrijeđanje u zatvorenim grupama

Ismijavanje i vrijeđanje u bilo kojem okružju pogrešno je ponašanje za tri četvrtine ispitanih nastavnika, ali tek za malo više od polovice ispitanih učenika. Učenici smatraju da prosudba nekog ponašanja ovisi o kontekstu (otvorena/zatvorena grupa).

\subsection{Ismijavanje i vrijeđanje na internetu može ozbiljno povrijediti osobe na koje je usmjereno}

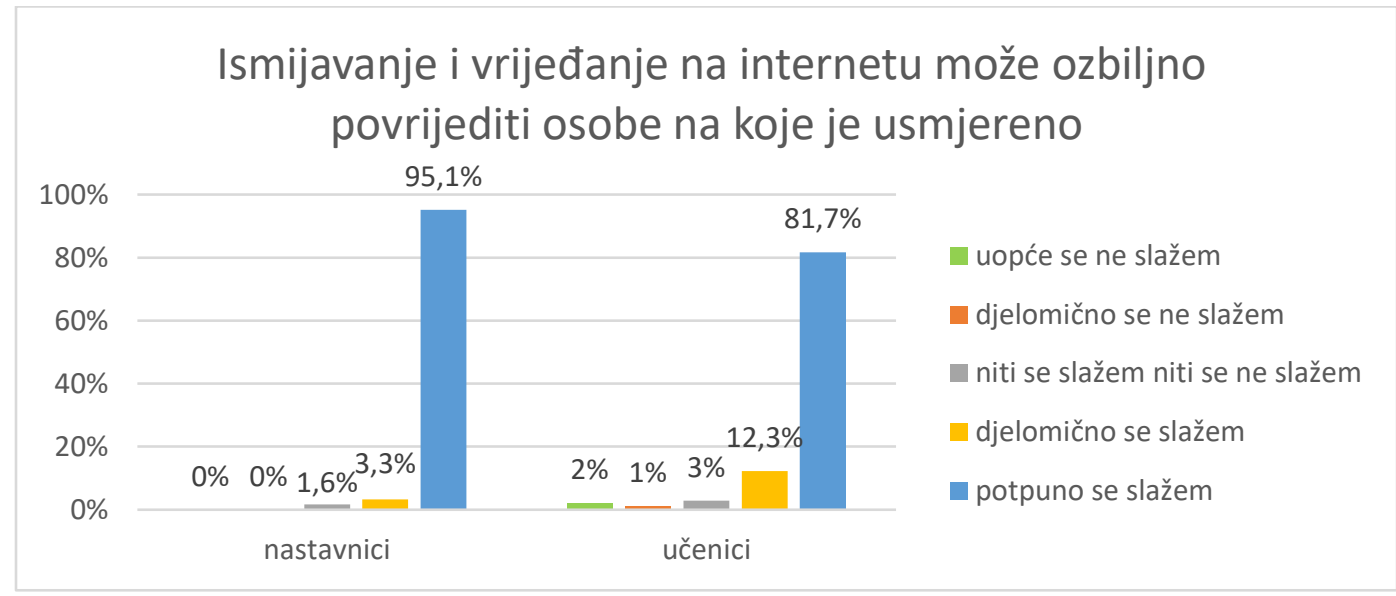

Grafikon 13. Ismijavanje i vrijeđanje - povreda osobe

Velika većina ispitanika je svjesna koliko ozbiljno može biti ismijavanje i vrijeđanje, tj. zlostavljanje na internetu. Ipak, mali postotak učenika (oko 2\%) ne prihvaća da osoba ismijavana i vrijeđana na internetu može biti ozbiljno povrijeđena. 


\subsection{Ismijavanje na internetu ne treba shvatiti ozbiljno}

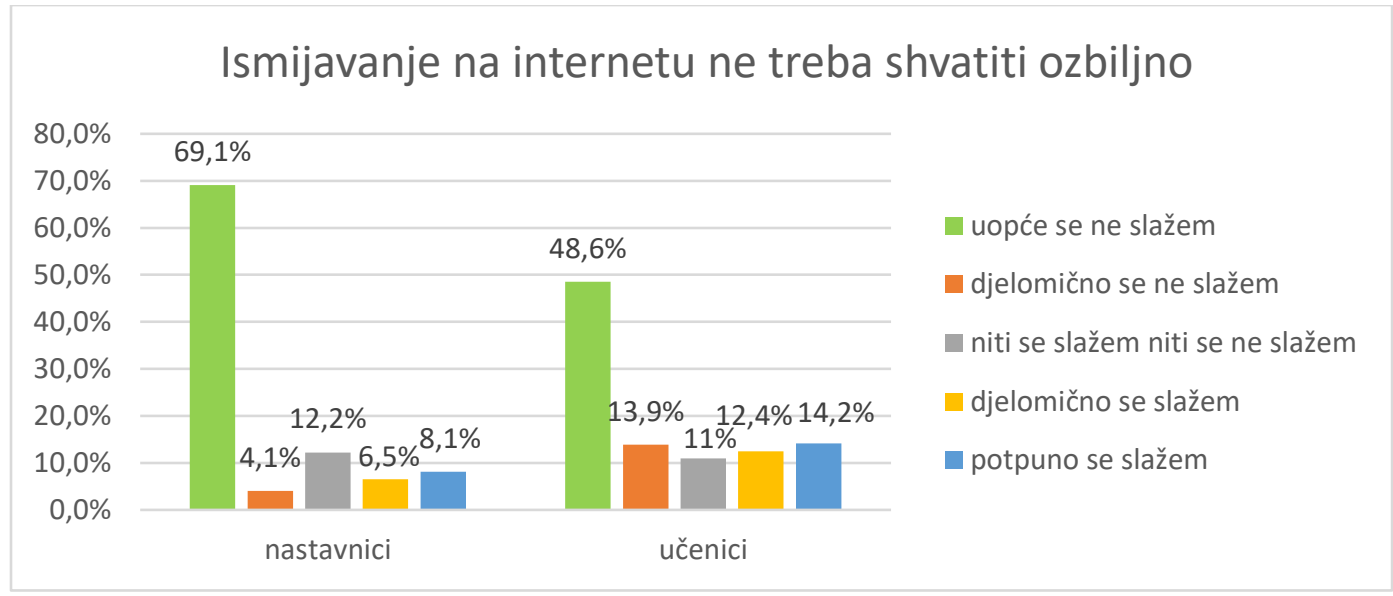

Grafikon 14. Ismijavanje na internetu ne treba ozbiljno shvatiti

Manje od $10 \%$ profesora misli da ismijavanje na internetu ne treba shvatiti ozbiljno, a u učeničkoj populaciji taj je postotak veći od $10 \%$. Isto tako značajno je veći postotak profesora koji takvo ismijavanje smatraju ozbiljnom pojavom (skoro 70\%), a isto misli tek oko $50 \%$ učenika.

\subsection{Ako se nekoga ismijava i vrijeđa na internetu, nije odgovoran samo onaj tko to objavi, već i onaj tko ,lajka" te objave}

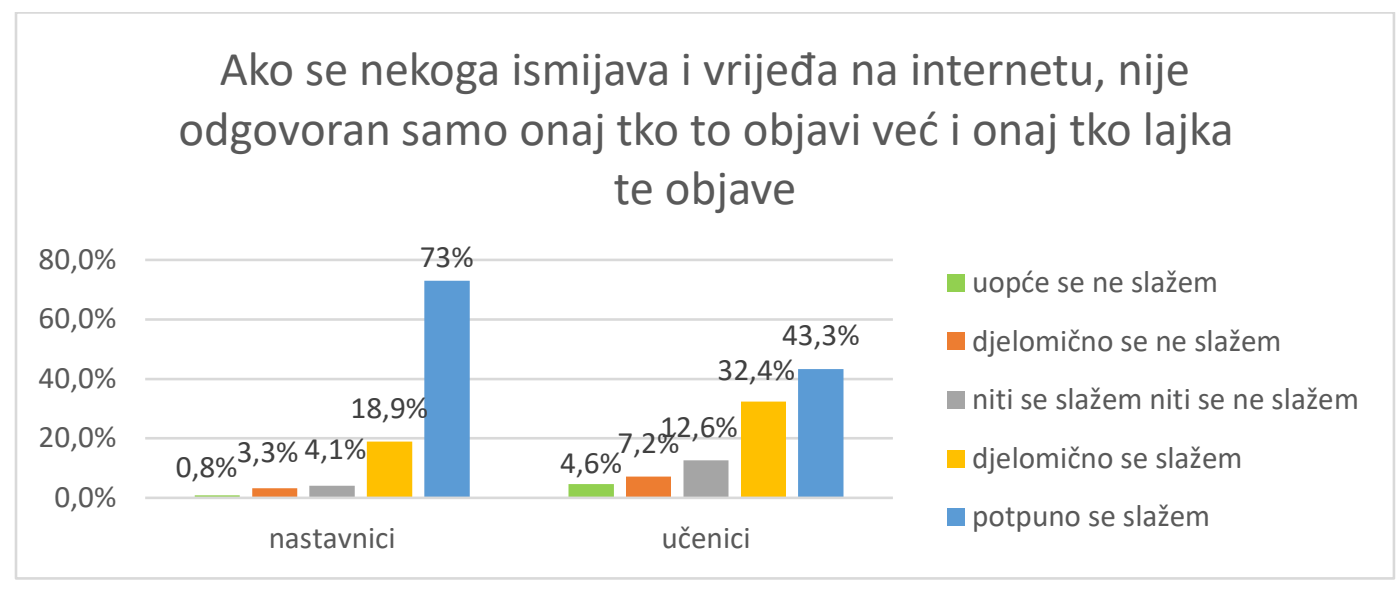

Grafikon 15. Tko je odgovoran za ismijavanje i vrijeđanje na internetu

Razlika u odgovorima između profesora i učenika je velika, čak 30\%. Profesori više uočavaju da postoji odgovornost i onoga tko je pozitivno reagirao na uvredljivi sadržaj 
S. Perić, G. Sekulić-Štivčević, D.Marušić Brezetić, Etičko korištenje interneta i lažni profili

1.15. Ako je netko javna osoba (političar, pjevač, glumac...) treba prihvatiti da će ga se nekažnjeno ismijavati i vrijeđati na internetu

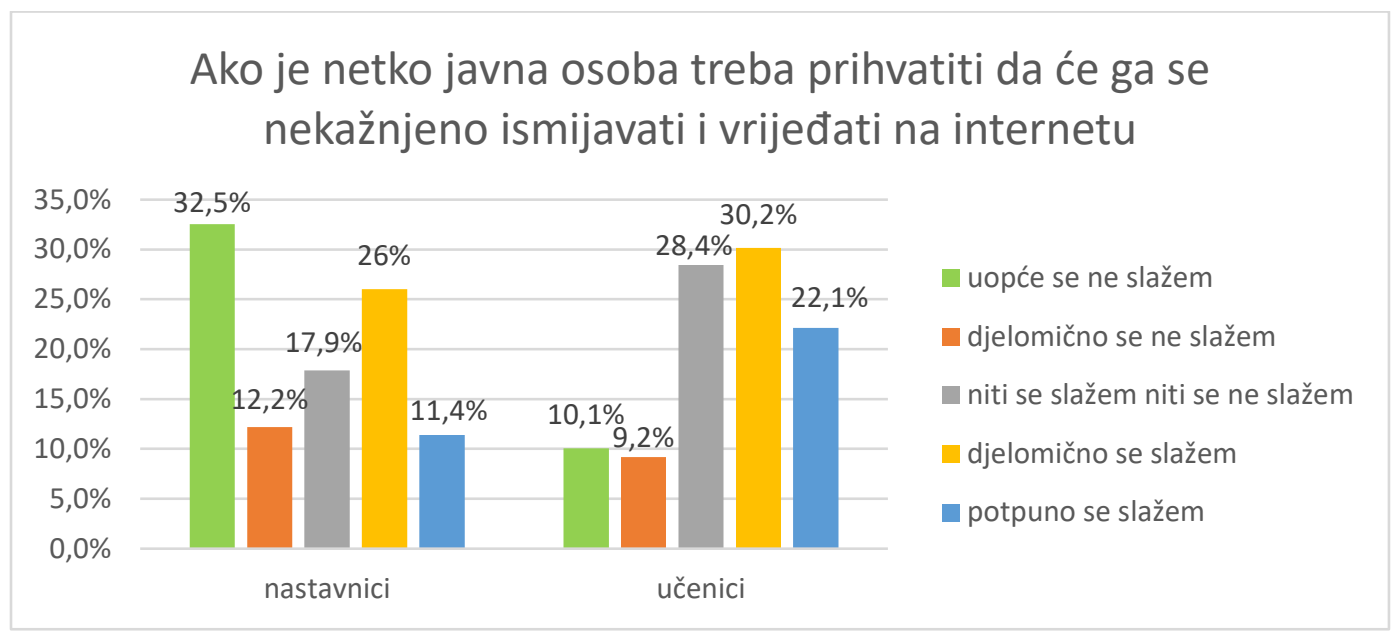

Grafikon 16. Ismijavanje i vrijeđanje javne osobe

Nastavnici i učenici jako različito razmišljaju

a kod učenika je dominantan odgovor da

o ovom problemu. Kod nastavnika najviše javna osoba donekle mora računati na takvu postotaka misli da je jednako pogrešno vrstu zabave drugih na njezin račun vrijeđati javne osobe kao i bilo koga drugoga,

1.16. Kod procjene je li nešto objavljeno na internetu uvreda ili nije, najvažnija je namjera onoga koji je taj sadržaj objavio

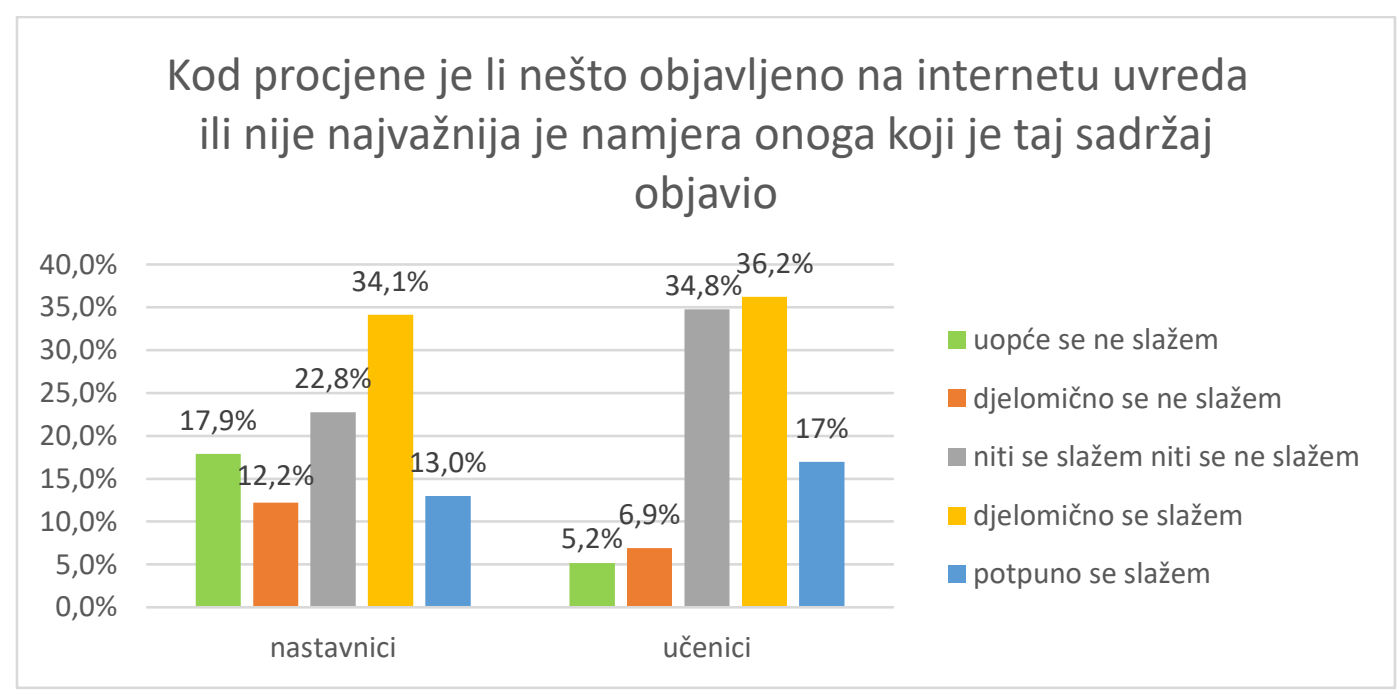

Grafikon 17. Značenje namjere kod procjene je li nešto uvreda 
Nastavnici i učenici na ovo pitanje odgovaraju podjednako: većina misli da je namjera vrijeđanja nekoga najvažniji element pri prosudbi neke internet objave (odgovori potpuno se slažem i djelomično se slažem). Dakle, ako je motivacija nešto drugo: zabava ili ukazivanje na društveni problem (satira) skloni su blagonaklonije gledati na to nego na objavu kojoj je cilj uvrijediti nekoga. Među onima koji misle da namjera nije odlučujući element za procjenu nečije moralne odgovornosti znatno je više profesora nego učenika.

\subsection{Kod procjene je li nešto objavljeno na internetu uvreda ili nije najvažnije je kako se osjeća onaj o kojemu je ta objava}

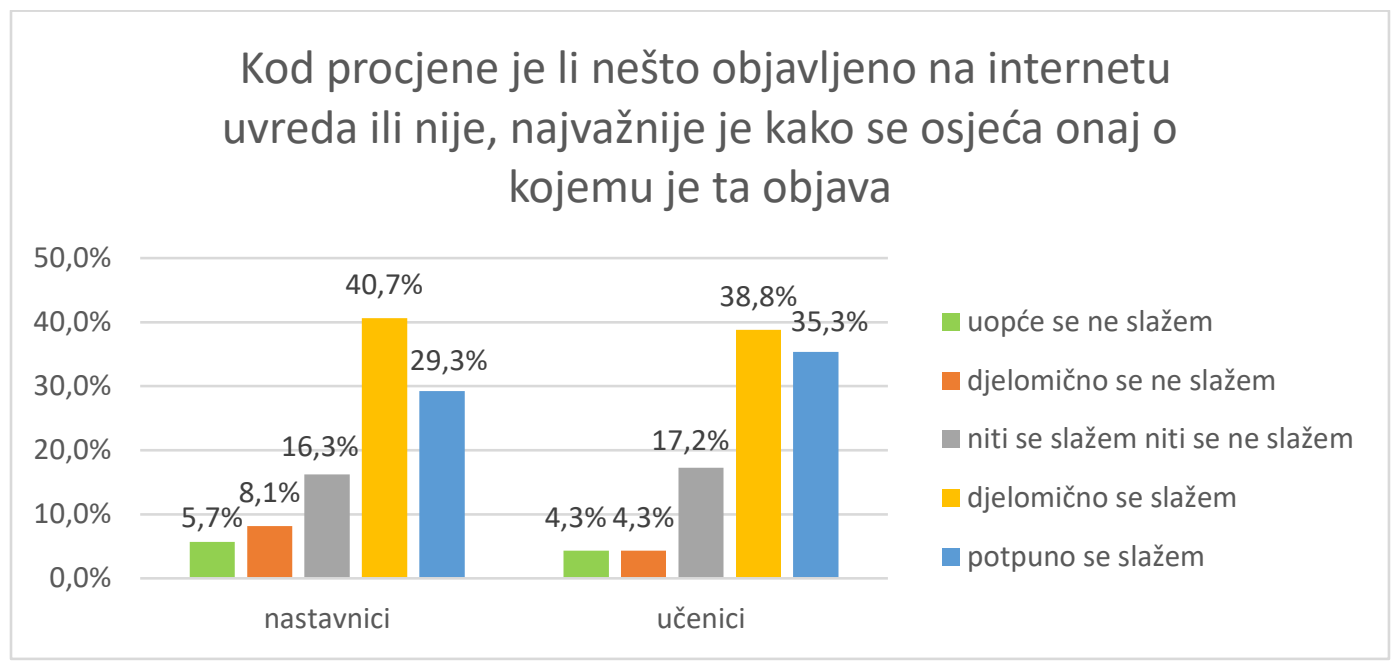

Grafikon 18. Značenje povrede osjećaja kod procjene je li nešto uvreda

Odgovori se djelomično preklapaju s prošlim pitanjem te bi se iz njih dalo zaključiti da ni ispitanici nisu bili sigurni treba li dati prednost namjeri ili posljedici, pa su se odlučivali za isti odgovor (djelomično se slažem). 


\subsection{Barem jednom sam se lažno predstavio ili dao lažne podatke o sebi}

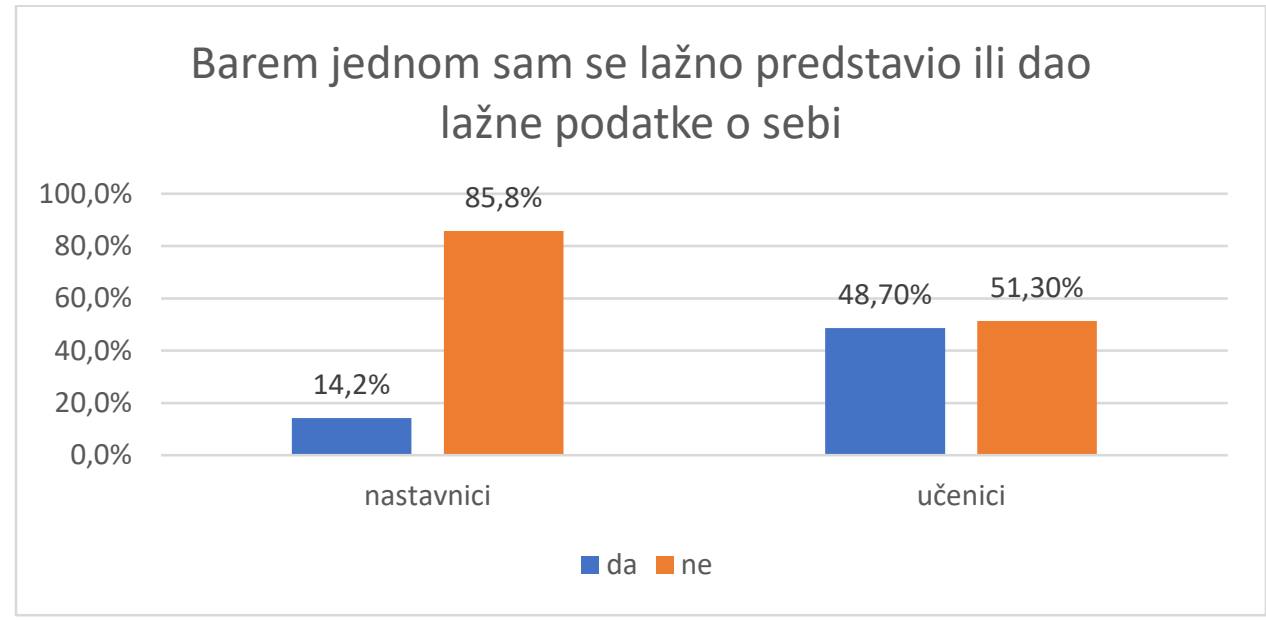

Grafikon 19. Lažno predstavljanje

Značajno veći postotak učenika poigravao se s vlastitim lažnim predstavljanjem (gotovo 50\%), sličnu praksu imalo je tek oko $15 \%$ profesora.

Razlika manja od 10\% u najčešćem odgovoru i profesora i učenika prisutna je u 8 pitanja. Razlika između 10\% i 20\% u najčešćem odgovoru je u 2 pitanja. Razlika od $20 \%$ do $30 \%$ kod najčešćeg odgovora je u 5 pitanja, a više od 30\% u 2 pitanja (1.2 i 1.19). Učenici i nastavnici se najviše razlikuju u tome koliko im smeta da se objavljuju njihove fotografije i u tome koliko su se često lažno predstavljali na internetu. Iako je u tim pitanjima razlika velika još uvijek se radi o tome da je $\mathrm{i}$ jedna $\mathrm{i}$ druga skupina dala isti najčešći odgovor. To nije bio slučaj u pitanjima 1.8, 1.16. Gotovo $70 \%$ profesora se potpuno slaže da mnogi objavljuju preintimne sadržaje na društvenim mrežama, a to misli samo tridesetak posto učenika. Kod učenika je najčešći odgovor da se tek djelomično slažu s tom tvrdnjom (ali i to tek četrdesetak posto). Očito se po pitanjima procjene javno-privatno, intimnoneintimno skupine izrazito razlikuju. Je li u pitanju veća osviještenost profesora o mogućnosti zlouporabe takvih sadržaja na internetu ili klasični generacijski jaz u kojem je starija generacija konzervativnija to se ne može utvrditi. U pitanju 1.16 je također različit najčešći odgovor. Najveći broj profesora se uopće ne slažu da javna osoba treba prihvatiti da će ga se nekažnjeno ismijavati i vrijeđati na internetu $(32,5 \%)$, dok 30,17\% učenika se djelomično slaže s tom tvrdnjom. Očiti su učenici puno više involvirani u različite šale, komentare i slično u kojima se govori o javnim osobama ili su 
naprosto na to puno više navikli nego profesori

\section{ETIČKI PRISTUP ANKETI}

Iako je virtualni svijet bliži učenicima nego profesorima ipak dio učenika smatra da ne vrijede ista moralna pravila $\mathrm{u}$ stvarnom $\mathrm{i}$ „nestvarnom“ svijetu. To je uočljivo već u odgovoru na prvo pitanje jer 30\% učenika smatra da ismijavanje nije jednako pogrešno ako je u virtualnom svijetu. Vrlina kao karakterna osobina jest dispozicija koja se pojavljuje u svim sličnim djelatnim situacijama. Dovodi do toga da se nekoga smatra dobrom osobom. Očito je da dio učenika nije do kraja razvio svoj moralni habitus, dio ih evidentno ne iskazuje dobrohotnost prema drugima $\mathrm{u}$ virtualnoj sferi. Iz pozicije Aristotelove etike moglo bi se reći da je za dio ispitanika nije razvio razboritost ( intelektualnu vrlinu ključnu za razvoj svih ostalih. U okviru te razboritosti ulazi i moralna snaga, mogućnost samosavladavanja čak i kad neprihvatljivo djelovanje ima privlačnu moć. U sljedeća dva pitanja ispitanici su iskazali stav vezan uz objavu fotografija bez dopuštenja onih koji su na njima. Iako mnogima smeta da se nađu na objavljenoj fotografiji, među njima sasvim sigurno postoje i oni koji su to i sami učinili drugima (među nastavnicima barem 15\%), čime su postupili u suprotnosti s Kantovim kategoričkim imperativom. Kao apstraktno formalno načelo kategorički imperativ je bezuvjetna naredba koji ne govori ni o jednoj konkretnoj situaciji već je primjenjiv na sve moralne situacije, a glasi ,radi tako, da maksima tvoje volje u svako doba ujedno može da vrijedi kao princip općega zakonodavstva“" (Kant, 1956: 38). Drugim riječima, ispravno je samo ono što možemo s odobravanjem zamisliti da rade svi ljudi u takvoj situaciji. Konkretno za ovaj primjer bi kategorički imperativ bio poštovan samo ako oni koji ne vole da im se objavljuje fotografija bez njihove dozvole ni sami ne objavljuju tuđe (ma kako im se to možda učinilo bezazleno i zabavno). Prema etici Immanuela Kanta dužnost činiti dobro neovisno o trenutnom raspoloženju i vlastitim naklonostima predstavlja jedini ispravni motiv moralnog djelovanja. Četvrto i peto pitanje tematiziraju pregledavanje tuđih digitalnih tragova bez znanja i dopuštenja onog tko ih je stvorio. Profesori u većoj mjeri razlikuju pasivno razgledavanje od aktivnog činjenja (korištenja tuđih podataka). Budući da bi u pravilu svakoga smetalo da netko pregledava njegove korisničke račune ponovo je primjetno odstupanje od kategoričkog imperativa, 
odnosno postoji nesrazmjer između kriterija kojeg se primjenjuje na sebe i onog koji se primjenjuje na druge. $\mathrm{S}$ druge strane, zanimljivo je da bi više učenika bilo spremno iskoristiti tuđu lozinku (aktivno činjenje) nego samo pogledati otvoren tuđi korisnički račun (pasivno činjenje). Pitanje 1.5. i 1.6. propituju konformizam ispitanika i procjenu vlastitog identiteta na temelju društvenih mreža. Lajk kao oblik davanja pohvale i podrške sam je po sebi pozitivan, međutim uočljivo je da dio nastavnika i učenika daje lajk iz pogrešnih motiva, tj. postupaju po hipotetičkom imperativu u kojem ponašanje nije motivirano samom dužnošću ili iskrenim sviđanjem već nekom drugom željom, u ovom slučaju željom za ugađanjem i nezamjeranjem. Veća grupa pitanja odnosila se na vrijeđanje $\mathrm{i}$ ismijavanje na internetu. Uočljivo je da dio učenika ne primjenjuje moralna pravila iz stvarnog, fizičkog svijeta na svijet interneta. Iako su svjesni da je ismijavanje uživo pogrešno, ono posredovano internetom za njih gubi predznak ozbiljnosti. U nekom smislu, može se zaključiti da niti jedna niti druga skupina nema do kraja razrađene etičke stavove u nekim pitanjima iz domene etičkog promišljanja djelovanja na internetu. Npr. postoji velika vjerojatnost da su osobe isto odgovorile i 1.17 i na pitanje 1. 18. (potpuno ili djelomično se slažem), a tražilo se da se izdvoji najvažniji faktor. Kada kao kriterij procjene moralnosti odlučujemo između toga treba li dati prednost uzroku djelovanja ili posljedici djelovanja nalazimo se na poljima deontološke i konzekvecijalističke etike. Razlika među njima leži upravo u određenju što je presudno $\mathrm{u}$ procjeni moralnog djelovanja. Pri posudbi je li nešto moralno ili nije deontološka etika procjenjuje motiv djelovanja. Najpoznatiji primjer je etika Immanuela Kanta prema kojoj je moralan isključivo onaj čin motiviran dužnošću. Deontološki pristup ne preispituje posljedice činidbe već uzroke zašto je nešto učinjeno. Naspram toga konzekvecijalističke etike (npr. utilitarizam ili hedonizam) procjenjuju moralnost ili nemoralnost čina ovisno o njegovoj posljedici. Sukladno tome, pitanja su naše ispitanike usmjerila da istoj temi pristupe na dva različita načina - je li u procjeni što je uvreda važniji razlog zbog kojeg je nešto napisano na internetu (deontološki pristup) ili je važnije kako se napisano odrazilo na onoga o kome se piše (konzekvencijalistički pristup.) Uočljivo je da ipak veći broj ispitanika (iz obje generacijske grupe) primarnom smatra posljedicu, a ne namjeru objavljivača. Iskrenost $\mathrm{i}$ istinoljubivost višekratno su na internetu izbjegli i učenici i profesori. Iako 
nije navedeno u pitanju (1.19), mogući su različiti razlozi takvog ponašanja. To može biti zlonamjerna želja da se nekoga prevari, ali i opravdana želja da se zaštiti vlastiti identitet (npr. kod igranja igrica na internetu). $\mathrm{U}$ tom smislu nije primjenjiv etički univerzalizam i teško bi bilo pronaći pravilo koje bi vrijedilo za sve situacije. U procjeni ovog ponašanja odlučujući bi mogao biti deontološki pristup - koja je namjera onoga tko stvara lažni identitet. Ukoliko je to namjerno dovođenje u zabludu onih s kojima se komunicira (zbog nekog osobnog, financijskog ili sličnog motiva) te ako su drugi uvjereni da je taj identitet istinit tada se definitivno radi o moralno neprihvatljivom činu. S druge strane, ako je namjera zaštita vlastitih osobnih podataka u nesigurnom Internet okruženju, a posebno ako oni $\mathrm{s}$ kojima se komunicira niti ne misle da bi se trebalo ostaviti pravo ime i prezime tada stvaranje lažnih profila ne bi naišlo na moralnu osudu. S obzirom na to ne bi bila primjenjiva klasična teorija vrlina koja bi naglasila važnost toga da se govori istina jer je polje moguće interakcije promijenjeno.

Moglo bi se zaključiti da dijelu učenika za cjelovitu moralnu prosudbu nedostaju i određena znanja o internetu ili o posljedicama koje komunikacija internetom može prouzročiti, Sokratovski govoreći oni griješe iz neznanja. „Za Sokrata vrlina je jednaka znanju (episteme) ili mudrosti (sofija). Iz stava da je vrlina znanje slijedi logički zaključak o jedinstvu vrline: sve vrline imaju stu bit, tj. praktičku racionalnost i mogu se učiti““ (Bošnjak, 1993: 156). Premda su u virtualnom životu dosta aktivniji od starijih generacija, učenička populacija manje je sklona promišljati o tuđem, a posebno o svojem djelovanju i njegovoj ispravnosti. Postoji velika vjerojatnost da im se ta pitanja neće spontano pojaviti pa im se zato treba pristupiti u obliku organizirane edukacije, s kojom opet treba biti oprezan da ne djeluje nametnuto i moralizatorski. Etičko promišljanje na stvarnim primjerima iz svakodnevnog života, usmjeravanje na pitanje zašto je nešto u redu ili nije u redu, a ne puko nabrajanje propisa koji reguliraju nešto područje djelovanja jedini je put do istinskog razumijevanja i promjena ponekih loših navika. Ovakva tema i ovakav pristup ulazi u opseg međupredmetnih tema koje su i definirane kao općeljudske vrijednosti i kompetencije čovjeka za 21. stoljeće. Osobito doprinosi temi Osobnog i socijalnog razvoja te Upotrebi IKT-a. Zato bi za primjenu bili pogodni satovi informatike, sociologije, etike, filozofije, ali i satovi razredne zajednice.

\section{ZAKLJUČAK}


S. Perić, G. Sekulić-Štivčević, D.Marušić Brezetić, Etičko korištenje interneta i lažni profili

Hipoteza o bolje definiranim stavovima profesora nego učenika u većoj je mjeri potvrđena. Ispitanici među profesorima $\mathrm{u}$ većini pitanja imaju ujednačenije stavove (najzastupljeniji odgovor) nego ispitanici među učenicima, tj. razlika između najzastupljenijeg odgovora i onog sljedećeg po broju glasova je veća među profesorima nego među učenicima. Sukladno tome najzastupljeniji odgovor među profesorima ima veći postotak nego najzastupljeniji odgovor među učenicima. Izuzetak su pitanja 1. 10 o objavljivanju snimki nesreća gdje je najzastupljeniji odgovor kod učenika za gotovo $7 \%$ viši nego kod profesora, a određena odstupanja su vidljiva i u pitanjima 1.16 i 1.17 gdje je razlika među odgovorima jedne $\mathrm{i}$ druge grupe puno manja te ima kolebanja i kod jednih i kod drugih ispitanika

\section{LITERATURA}

1. Ess \& AoIR 2002; King 1996;

Samuel and Buchanan, 2020.

2. Kant, I. 1956. Kritika praktičnoga

uma. Zagreb. Kultura.

3. Bošnjak, B. 1993. Povijest filozofije.

Zagreb. Nakladni zavod Matice

hrvatske.

4. https://www.medijskapismenost.hr/k reiranje-laznih-profila-i-laznopredstavljanje/

5. https://mup.gov.hr/gradjani281562/savjeti-281567/nasilje281582/zlostavljanje-suvremenimtehnologijama-mobitel-i-internet12214/rizici-i-opasnosti-nadrustvenim-mrezama/281997

\section{SUMMARY}

\section{ETHICAL INTERNET USE AND FAKE PROFILES}

In mid-2020, a survey of 477 respondents (354 students and 123 teachers) was conducted. The survey questioned the attitudes of students and teachers from several schools about different situations related to the use of the Internet and leaving digital traces. Among the survey questions there were 19 questions related to the ethical use of the Internet. The initial hypothesis was that teachers have better defined attitudes about ethical issues than students. We assumed that, given that it concerns a very current, present-day issue and given the profession they do, teachers give more thought to the dangers of the Internet and have more firmly formed moral attitudes. The survey largely supported the hypothesis.

Key words: school, internet, ethics, fake profiles. 